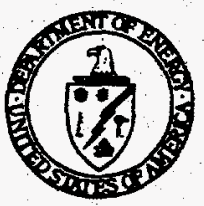

\title{
RCRA Contingency Plans and Emergency Procedures
}

\begin{abstract}
BACKGROUND: RCRA requires that owners and operators of hazardous waste treatment, storage, and disposal tacilities develop and implement contingency plans defining effective actions to minimize unanticipated damage from any treatment, storage, or disposal of any hazandous waste.
\end{abstract}

STATUTES: Resource Conservation and Recovery Act (RCRA) of 1976 and Hazandous and Solid Waste Amendments (HSWA) of 1984.

REGULATIONS: 40 CFR 264.50-264.56, 265.50-265.56, and 270.42.

REFEAENCES: Final Rule: 45 FR 33221, May 19, 1980.

Amendments: 46 FR 27480, May 20, 1981; 48 FR 30115, June 30, 1983; 50 FR 4514, January 31, 1985; 53 FR 37935, Sept. 28, 1988; 53 FR 37939, Sept. 28, 1988; 53 FR 41649, Oct 24, 1988; 54 FR 9607, March 7, 1989.

\section{U.S. Environmental Protection Agency, Permit Applicants' Guidance Manual for the General Facility} Standands of 40 CFR 264, PB87-151064, 1983.

DOE Orders 5400.3, 5500.1B, 5500.2B, 5500.3A and 5500.10.

EH-231 Memorandum to M.W. Tiernan, Richland Operations Office, Subject: Distribution of Hazardous Material/Waste Contingency Plans, March 22, 1990.

\section{What is a RCRA contingency plan?}

The plan sets out an organized, planned, and coordinated course of action to be followed to minimize hazards to human health or the environment from fires, explosions, or unplanned sudden or non-sudden releases of hazardous waste or hazardous waste constituents.

\section{Who must prepare a RCRA contingency plan?}

Contingency plans must be prepared and implemented by owners and operators of interim status and permitted hazardous waste treatment, storage, and disposal facilities.

\section{When must the contingency plan be submitted to the regulatory agency?}

The contingency plan must be submitted to the EPA Regional Administrator or authorized state with the Part B permit application (40 CFR 264.53).

\section{What should a contingency plan contain?}

The plan must describe actions taken to comply with and implement the plan (40 CFR 264.51). The plan must show that emergency procedures will be implemented immediately whenever an emergency occurs at the facility. If a facility already has in place a Spill Prevention, Control, and Countermeasures (SPCC) Plan in accordance with 40 CFR 112, or Part 1510 of Chapter $V$, or other emergency or contingency plan, amendments to that plan may fulfill these requirements.

Does this mean that compliance with applicable DOE Orders that require an emergency plan may satisfy the RCRA contingency plan requirements?

Yes. If amended as needed to meet the regulations, an emergency plan prepared according to DOE Orders can fulfill the RCRA contingency plan requirements.

\section{When are the provisions of a contingency plan to be carried out?}

The provisions of a contingency plan must be carried out immediately whenever there is a fire, explosion, or release of hazardous waste or hazardous waste constituents that could threaten human health or the environment. 


\section{Are any specific components of a contingency plan required by the regulations?}

Yes, the following five components have been specified in the regulations (40 CFR 264.52):

Emergency procedures facility personnel must take in response to fires, explosions, or hazardous waste releases;

A coordinated emergency services plan agreed to by local police departments, fire departments, hospitals, and state and local emergency response tearns;

A list of emergency coordinators that includes names, addresses, and telephone numbers of all persons qualified to act as emergency coordinators;

A list of emergency equipment, including location, physical description, and capabilities of each item listed; and

An evacuation plan for the safe egress of facility personnel.

\section{Are any specific emergency procedures required by the regulations?}

Yes, and these procedures must be discussed in the contingency plan. The eight emergency procedures to be implemented when a fire, explosion, or hazardous waste release occurs are defined in 40 CFR 264.56. These procedures include activation of internal alarms or communication systems, notification of appropriate state or local agencies, assessment of hazards to human health and the environment, and reporting requirements.

\section{To whom must copies of the contingency plan be distributed?}

In addition to maintaining a copy (or copies) of the contingency plan at the facility; copies must be submitted to local police departments, fire departments, hospitals, and state and local emergency response teams that may provide emergency services to the facility (40 CFR 264.53). Even if a DOE facility will be providing its own responders, the contingency plan still should be sent to appropriate authorities in the local community in case of an off-site release or major emergency that requires their assistance. Individual copies of the contingency plan should be numbered. A facility should maintain a log identifying each copy and its location.

\section{Under what circumstances should a contingency plan be amended?}

A contingency plan must be reviewed and immediately amended whenever:

the facility permit is revised;

the plan fails in an emergency;

the facility design, construction, operation, maintenance, or other circumstances change to increase the potential for fires, explosions, or releases of hazardous wastes or hazardous waste constituents, or change the response necessary in an emergency;

emergency coordinators are changed; or

emergency equipment changes.

For permitted facilities, changes to the plan generally will be handled as Class I or II permit modifications (40 CFR 270.42, Appendix I, A.6).

For interim status facilities, changes to the plan should be sent to the agency reviewing the Part $B$ permit application as they are made. Submitting changes after the Part B permit is issued would trigger. the permit modification procedures noted above.

\section{Who is responsible for committing resources needed to carry out a contingency plan?}

Each facility must have an emergency coordinator responsible for implementing and coordinating all emergency response measures (40 CFR 264.55). At all times, an emergency coordinator must be either on-site or on call (i.e., available to respond to an emergency by reaching the facility in a short period of time). The emergency coordinator must be thoroughly familiar with all aspects of the contingency plan, all operations and activities, location and characteristics of waste handled, location of all records, and facility layout.

\footnotetext{
Questions requlring policy decisions will not be dealt with in EH-231 Information Briets unless that policy already has been esfablished through appropriate. documentafion. Please refer any questions concerning the subject material covered in this Information Briel to Jean SChumann, RCRAVCERCLA DIVISIOn, EH-231, FTS 896-7769.
} 


\section{DISCLAIMER}

This report was prepared as an account of work sponsored by an agency of the United States Government. Neither the United States Government nor any agency thereof, nor any of their employees, make any warranty, express or implied, or assumes any legal liability or responsibility for the accuracy, completeness, or usefulness of any information, apparatus, product, or process disclosed, or represents that its use would not infringe privately owned rights. Reference herein to any specific commercial product, process, or service by trade name, trademark, manufacturer, or otherwise does not necessarily constitute or imply its endorsement, recommendation, or favoring by the United States Government or any agency thereof. The views and opinions of authors expressed herein do not necessarily state or reflect those of the United States Government or any agency thereof. 


\section{DISCLAIMER}

\section{Portions of this document may be illegible in electronic image products. Images are produced from the best available original document.}

